\title{
三島溶岩流内地下水の年代について
}

\author{
馬原保典 ${ }^{*} \cdot$ 五十嵐敏文 $* *$ 田中靖治 ${ }^{*} *$

\section{Groundwater Ages of Confined Aquifer in Mishima Lava Flow, Shizuoka}

\author{
Y. Mahara**, T. Igarashi** \\ and Y. Tanaka**
}

\begin{abstract}
This study focused on developing a tritium and helium $-3\left({ }^{3} \mathrm{H}^{-3} \mathrm{He}\right)$ dating method to survey the flow of groundwater in a large geohydrologic catchment area with groundwater basins including candidate disposal sites for wastes. The dating method is based on counting the increase of ${ }^{3} \mathrm{He}$ produced by beta decay of tritium in groundwater. Precise detection of ${ }^{3} \mathrm{He}$ is very difficult because the ratio of ${ }^{3} \mathrm{He}$ to ${ }^{4} \mathrm{He}$ is generally less than $10^{-6}$ for $10^{-8}$ ccSTP of helium dissolved in one gram of groundwater. We developed an isolating sampling method for groundwater in which atmospheric air is prevented from contacting groundwater sample and the ${ }^{3} \mathrm{He}$ is measured by mass spectrometry. We applied this dating method to the confined aquifer in the Mishima lava flow located in the east side of Mt.Fuji. The measured age of groundwater is aligned young to old following the groundwater flow. The groundwater in the Mishima area was grouped into two different sources based on the measured groundwater ages and the stable isotope composition $\left(\delta \mathrm{D}\right.$ and $\delta^{18} \mathrm{O}$ ). The movement of groundwater in the lava flow was calculated to be an approximate $16 \mathrm{~m}$ /day based on the difference between the groundwater ages measured at two sampling sites (Izushimada and Kakitagawa) and the geographical distance. This is in good agreement with results measured by radioisotope flow meter in a geohydrologic investigation 20 years ago and calculated by Darcy's law.
\end{abstract}

key words: dating groundwater, trituim, tritiogenic helium -3 , stable isotopes, Mishima Lava Flow.

\section{1. はじめに}

**電力中央研究所 我孫子研究所原燃サイクルプロ 廃棄物処分の環境影響評価ならびに地下水資源の ジェクト部処分チーム 
握することが重要である。その際、水の循環速度と りわけ地下での水の滞留時間と地下での異なる滞留 時間の地下水の混合割合を知ることは、地下水流動 評価の上できわめて意義深いことである。このため 一つの方法として、地下水の水質を調べることに よって地下水の流動を把握しようとする新しい技術 開発の試みが近年盛んとなっている。地下水の適切 な水質因子を選択すれば、地下水を包蔵する周辺岩 盤の環境条件をも推定することが可能となる。その 意味では、地下水に溶存してる物質は天然のトレー サーと考えることができる。

天然トレーサーを用いた地下水調査には、(1)溶存 イオン量・溶存ガス量あるいは、重水素(D)重酸素 $\left({ }^{18} \mathrm{O}\right)$ 等の同位体比の変動によって地下水の流域区 分や涵養源等の推定(Sugisaki, 1961 : 吉岡他、1979 : 水谷·小田、1983：Rauert.et al, 1974：Burgman,et al., 1978 : Rodhe. 1983)、(2)天然地下水中に 存在する放射性核種の放射壊变の速度より地下水の 年代(滞留時間)を推定(北岡、1983：木村、1986： Paul, 1986 : Martin, 1985 : Bentley et al., 1986 : Philips et al., 1986)する方法とがある。これらの内で 地下水に含まれ地下水と同一挙動をとると考えられ ている天然放射性トレーサー ${ }^{3} \mathrm{H} 、{ }^{14} \mathrm{C} 、{ }^{36} \mathrm{Cl} 、{ }^{129} \mathrm{I}$ 等 (Kaufman • Libby., 1954 : Kaufman, 1961)の地下水 中濃度の経時的変化を測定することによって地下水 の滞留時間を直接推定することができるのは、放射 性核種の活用による年代決定法である。地下水の年 代測定に用いられる最もポピュラーな核種は、 ${ }^{3} \mathrm{H}$ と ${ }^{14} \mathrm{C}$ であるが、測定結果を基に直接的に地下水の 流速を求める程の精度は期待できない。また、我国 のように降雨量の多い地域で、浅層地下水の水循環 が比較的速い場合には ${ }^{3} \mathrm{H}$ を用いた比較的短い地下 水年代測定は有効と期待されるが、最近のように降 水中の ${ }^{3} \mathrm{H}$ 濃度の低下が著しい場合には、同一地点 に扔いて長時間 $(2 \sim 5$ 年)連続測定を行わなければ 地下水年代の推定は、困難となりつつある(北岡 · 吉岡、1984：本島、1987)。このような状況を考え ると、一回の測定で年代の決定が可能となるような 測定法の開発が望まれる。この ${ }^{3} \mathrm{H}$ 法の欠点(長期連 続測定、推定限界時間～数 10 年)をおぎない一回の 測定で滞留時間としては、最長100年程度までの推 定を可能とする方法として ${ }^{3} \mathrm{H}-{ }^{3} \mathrm{He}$ 測定法の適用が 考えられる(Torgersen et al., 1977, 1979: Mamyrin • Tolstikhin, 1984: Takaoka • Mizutani, 1987;
Soloman - Sudicky, 1991: Kamensky et al., 1991: Stute et al.; 1992)。

本研究では、 ${ }^{3} \mathrm{H}-{ }^{3} \mathrm{He}$ 年代測定法を三島溶岩流地 下水に適用し、その他の調査結果とも組合せ、地下 水の起源の同定と流域区分を試み、地下水調查の一 手段として地下年代測定が有効であることを示す。

\section{2. 地下水年代決定原理と採水・分析}

\section{2. $1{ }^{3} \mathrm{H}-{ }^{3} \mathrm{He}$ 法年代決定原理}

議論を簡単にするために図ー 1 に示すような上下 を不透水層で区切られた被圧地下水層を考える。今、 ある固有のトリチウム濃度を持った降水が地下に浸 透し地下水を涵養すると考える。一度地下に浸透し た降水に対しては、周辺地層からの ${ }^{3} \mathrm{H}$ 供給は、ウ ラン・トリウムの含有量が少なく、中性子密度が小 さな場合には、殆ど無視できる程度であり (Morrison・Pine, 1955: Andrews et al., 1989)、かつ 地下水の流れがピストン流と仮定でき、そこでは流 れによる混合拡散も小さいと考えると地下水の ${ }^{3} \mathrm{H}$ 濃度は、浸透初期の降水の ${ }^{3} \mathrm{H}$ 濃度と滞留時間の関 数となり式(1)で表すことができる。ただし、この 場合には $\left({ }^{3} \mathrm{He} /{ }^{4} \mathrm{He}\right)$ 比が、大気へリウム成分等に比 ベ著しく高いマントルヘリウム成分の混入がないと の暗黙の仮定も含まれている。

$$
\begin{array}{rll}
\mathrm{C}_{\mathrm{t}}=\mathrm{C}_{\mathrm{o}} \mathrm{e}^{-\lambda \mathrm{t}} & \\
\text { ここに } \mathrm{C}_{\mathrm{t}} & ; \text { 採水時の }{ }^{3} \mathrm{H} \text { 濃度 }(\mathrm{T} . \mathrm{U} .) \\
\mathrm{C}_{\mathrm{o}} & ; \text { 地下水の初期 } 3 \mathrm{H} \text { 濃度 }(\mathrm{T} . \mathrm{U} .) \\
\lambda & ;{ }^{3} \mathrm{H} \text { の壊変定数 }(1 / \mathrm{T}) \\
\mathrm{T} & ; \text { 滞留時間 }
\end{array}
$$

しかしながら初期濃度Coについては、最近のよう に降水 ${ }^{3} \mathrm{H}$ 濃度が10T.U. 前後に低下してくると、長 期間の測定を行わなければ決定することが困難と なってきた。一回の測定で $C_{0}$ を決定する方法とし て、 ${ }^{3} \mathrm{H}$ が $\beta$ 壊変して生成される ${ }^{3} \mathrm{He}$ を同時に同一 試料水について測定できれば、式(2)より

$$
\left[{ }^{3} \mathrm{He}\right] \operatorname{tri}=\mathrm{Co}\left(1-\mathrm{e}^{-\lambda \mathrm{T}}\right)
$$

Co を決定できる。ただし $\left[{ }^{3} \mathrm{He}\right] \operatorname{tri} は 、{ }^{3} \mathrm{H} の \beta$ 壊 変によって生成される ${ }^{3} \mathrm{He}$ 原子の数である。

(1)(2)式より地下水年代(滞留時䦨)Tは、次式で推 定される。 

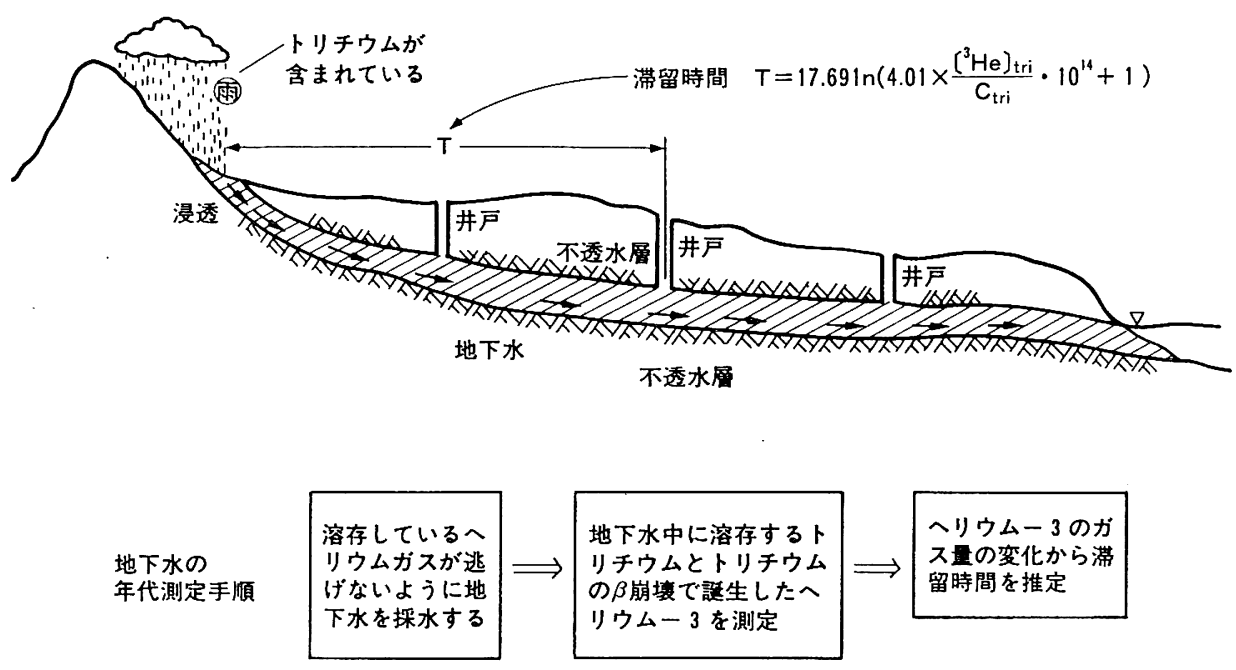

图一 $1{ }^{3} \mathrm{H}-{ }^{3} \mathrm{He}$ 法による地下水年代決定

Fig. 1. Determination of groundwater ages using the ${ }^{3} \mathrm{H}-{ }^{3} \mathrm{He}$ dating method

$$
\mathrm{T}=17.691 \mathrm{n}\left(4.01 \frac{\left[{ }^{3} \mathrm{He}\right] \mathrm{tri}}{\mathrm{Ct}} \cdot 10^{14}+1\right)
$$

ここに $\left[{ }^{3} \mathrm{He}\right]$ tri ; 地下水中 ${ }^{3} \mathrm{H} の \beta$ 崩壊によって 生成された ${ }^{3} \mathrm{He}$ 量 $(\operatorname{ccSTP} / \mathrm{g})$

$\left[{ }^{3} \mathrm{He}\right] \operatorname{tri}$ の評価ならびに式(3)の妥当性については、 Mamyrin・Tolstikhin(1984)等によって詳しく論ぜ らているのでそれらを参照されたい。

\section{2 . 2 地下水採水}

地下水中で ${ }^{3} \mathrm{H} の \beta$ 壊変によって生成された極微 量 ${ }^{3} \mathrm{He}\left(\sim 10^{-14} \mathrm{ccSTP} / \mathrm{g}\right)$ を高精度で分析するには、 まず生成した ${ }^{3} \mathrm{He}$ を逃さないよう、また大気と接触 しないよう気密状態で採水する必要がある。

井戸等の中で大気との接触を遮断し採水するため に、実際には、採水試料管の上下に止水弁 (近止弁) を設けそれを所定の深度まで降下させることによっ て採水を行う。止水弁はその降下の間は開いており、 自由に地下水は採水試料管内を流れ、一度止めて採 水試料管を引き上げる時には止水弁が働き、その深 度での地下水試料が採水試料管内に閉じ込められる 構造となっている。

採水試料管(内径 $8 \mathrm{~mm}$ 銅管肉厚 $1 \mathrm{~mm}$ )には、試 料水の密封性能を考慮し神戸製鋼所製冷蔵庫用なま し銅管(JISH3300 C1220T-0)を使用した。本採水シ
ステムによって原位置に扔いて採水試料管内に採取 された地下水は、逆止弁が働いたままの状態で地上 に引き上げ、なまし銅製の採取試料管の両端を直接 鋼製クランプで締め付け密封する。この方法を用い るとなまし銅がクランプエッジによって引き延ばさ れ完全に密着し溶存ガスの漏洩と外からの大気ガス の侵入を防ぐことができる。この方法を用いると、 地下水中に溶存するへリウムは、10000年でわずか $0.1 \%$ が逸散するに過ぎないと Weiss（1968）は述べ ている。この採水方法では、 ${ }^{3} \mathrm{He}$ の分析に必要な試 料水量として、 $15 \mathrm{ml}$ 程度の採取が可能である。

\section{3 溶存希ガス分析}

${ }^{3} \mathrm{He}$ 分析のためには、採取した地下水試料より溶 存ガスの抽出とその精製後、質量分析器へ導入し、 ${ }^{4} \mathrm{He}$ 絶対量と $\left({ }^{3} \mathrm{He} /{ }^{4} \mathrm{He}\right)$ 比を測定する。また、地下 水の涵養温度ならびに過剩大気の混入判定のため に、Qマスを用いた $\left({ }^{4} \mathrm{He} /{ }^{20} \mathrm{Ne}\right)$ 比の測定の必要が ある。

溶存ガス抽出は、なまし銅管製の採水試料管を抽 出装置に接続し、系全体を超真空状態 $\left(\sim 10^{-8} \mathrm{mbr}\right)$ とした後、採水試料管を密䦥している真空系側の銅 製クランプをはずし銅管の密着部分を押し拡げ一度 試料水をステンレス製の水容器に落とす。水容器に 移された試料水から10分間高周波洗浄器を用いて溶 
存ガスを追い出しながら液体窒素で冷却した活性炭 上に水蒸気と共に捕取する。この抽出方法によりほ ほ活性炭に溶存ガスの $95 \%$ が捕取される。この抽出 率は $20^{\circ} \mathrm{C}$ で蒸留水を大気と溶解平衡にした後、地下 水の採水に用いた同じ採水試料管に同じ鋼製クラン プを用いて蒸留水約 $15 \mathrm{~m} \ell$ を封入し、上記と同様の 抽出操作を10個の試料に対し行い、測定した結果と 理論溶解量 (Weiss 1971) と比較し決定した。従っ て、この抽出率の中にはブランク効果を含んだ結果 となっているものと解釈される。

溶存ガスを捕取した活性炭トラップを抽出装置か らはずし、溶存ガス清浄化装置に接続し、一度系全 体を超真空 $\left(\sim 10^{-9} \mathrm{mbr}\right)$ にした後 2 所に設けた液 体窒素で冷やしたU字管を通して水蒸気㧍よび凝 縮性のガス成分を除去する。さらにチタン・ゲッ ターポンプによって活性ガス成分(例えば $\mathrm{H}_{2} 、 \mathrm{~N}_{2}$ 、 $\mathrm{O}_{2}$ 、炭化水素等)を除去した後、He 分析に不要な $\mathrm{Ar}$ 、 $\mathrm{Kr} 、 \mathrm{Xe}$ の不活性ガス成分を液体窒素で泠却した活 性炭上に捕取除去した後、残存ガスである $\mathrm{He}$ と $\mathrm{Ne}$ を質量分析器 (VG-5400、英国 VG 社製)に導人し、 ${ }^{4} \mathrm{He}$ 量および $\left({ }^{3} \mathrm{He} /{ }^{4} \mathrm{He}\right)$ 比を同様の操作によって処 理した空気試料より作成した標準 He 試料と比較し 測定した。な㧍、標準空気の ${ }^{3} \mathrm{He} /{ }^{4} \mathrm{He}$ 比の值につ いては、常に更新されてきているが、ここでは Sano et al. (1984), Sano.Wakita (1985), Graham et al.(1987), Poreda et al.(1988)等が用いた值 $1.4 \times$ $10^{-6}$ を採用した。写真一 1 に測定装置の全景を示 す。

分析の測定上の精度としては、 $\left({ }^{4} \mathrm{He}\right)$ と $\left({ }^{3} \mathrm{He} /{ }^{4} \mathrm{He}\right)$ 比は、各々 $1 \%$ と $0.5 \%$ の測定誤差を含んでいる。 15〜17(g)の地下水中に含まれる ${ }^{3} \mathrm{He}$ 量としては、 概ね $10^{-15} \mathrm{cSSTP} / \mathrm{g}$ オーダーまで測定が可能であ る。な㧍、 ${ }^{4} \mathrm{He}$ 量の測定誤差としては、標準空気 $0.16 \mathrm{cc}$ 中に含まれる ${ }^{4} \mathrm{He}$ 量を20回づつ一定容積を持 つ溶存ガス清浄化装置内に拡散させた後、バルブで 清浄化装置を区切って質量分析器に導入する ${ }^{4} \mathrm{He}$ 量 を変化させながら出力と ${ }^{4} \mathrm{He}$ 量の関係を表わす検量 線を最小自乗法を用いて作成した。その時の相関係 数誤差が $1 \%$ 程度である。また、 $\left({ }^{3} \mathrm{He} /{ }^{4} \mathrm{He}\right)$ 比は、 同一試料に対する測定上の繰り返し誤差としては、 $0.5 \%$ 程度を含んでいる。また、 $\left({ }^{20} \mathrm{Ne} /{ }^{4} \mathrm{He}\right)$ 比は、 質量分析計に導入した後の $\mathrm{He} 、 \mathrm{Ne}$ 試料をQママス(マ スメート100アルバック社製)に導入し測定した。そ の測定精度は、 $10 \%$ 程度の測定誤差を含むものと思 われる。この誤差の見積もりとしては、標準空気試

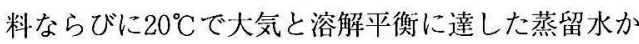
ら抽出した溶存 $\mathrm{He}-\mathrm{Ne}$ 比の繰り返し測定結果と Weiss(1971)の理論溶解度比の結果と比較し推察し た。なお、計測時のブランク ${ }^{4} \mathrm{He}$ 量の評洒としては、 スタンダードとした標準空気パイペット0.16cc中

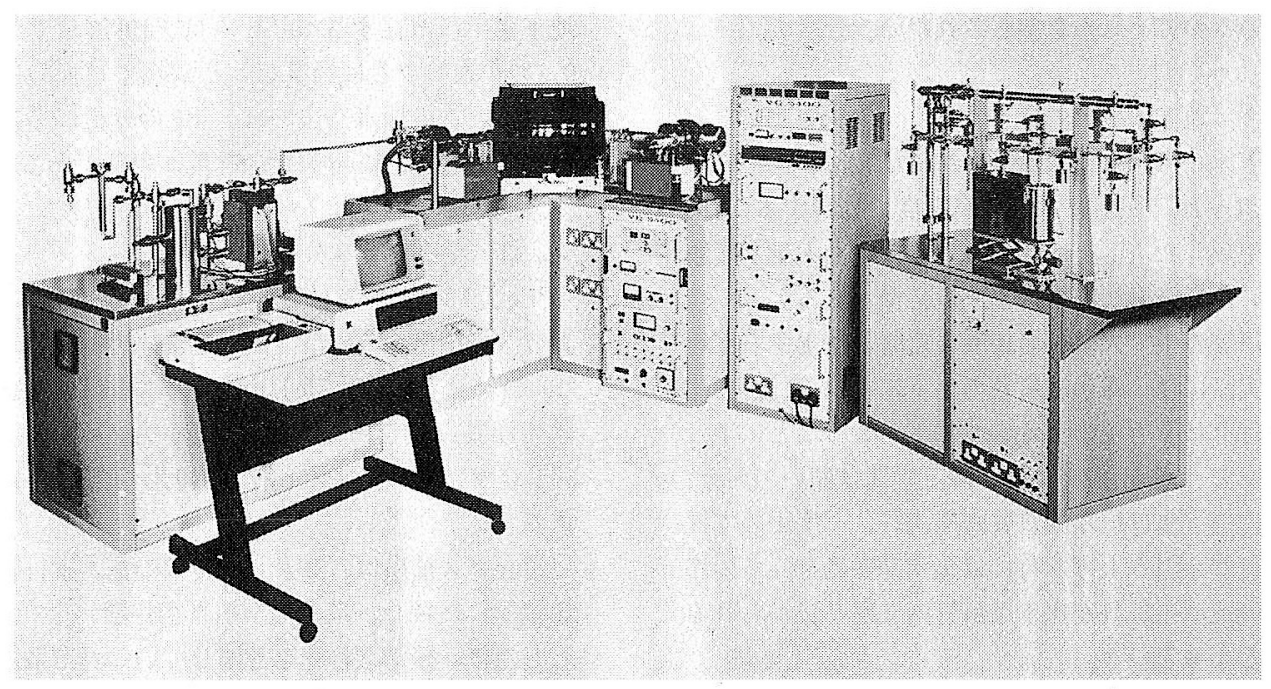

写真 1. 溶存ガス抽出、ガス清浄化ライントと質量分析器(VG-5400)の全景

Picture 1. The whole view of the extraction line of the dissolved gases of groundwater samples, the purification unit and the mass spectrometer (VG-5400). 
の $\mathrm{He}$ に対する出力約 $0.80 \mathrm{mV}$ に対し、ブランクテ スト時の He に対する出力は約 $0.02 \mathrm{mV}$ である。す ベての測定結果の整理においては、このブランク時 出力分を差し引くことによりブランクの影響は考虑 した。

\section{3. 三島溶岩流内地下水の年代測定}

\section{1 水理地質概要}

蔵田(1962)、金子・落合(1966)、落合・川崎(1970) 等の報告を基に三島溶岩流の構造の概要をまとめる と以下のように記述できる。『玄武岩を主体とする 三島溶䂟流は、富士山南東斜面須山地に源を発し愛 鷹山、箱根山の裾合谷を流下し表層部は三島市楽寿 園付近で止まっているが、一部はさらに南下し、柿 田川さらに沼津方面に延びている。三島市内および 柿田川の各湧泉群はこの溶岩流の末端部分に位置し ている』。この溶岩流の間隙率は、伊豆島田付近で の測定によれば10～90\%と大きく平均的には30〜 $40 \%$ 程度であり、溶岩層全体での平均透水係数は、 $0.029 \mathrm{~m} / \mathrm{sec}$ と見積もられている(金子・落合、 1966 ：落合・川崎、1970)。

\section{2 地下水採取}

三島溶岩流内の地下川主流上に位置すると考えら れる伊豆島田にある深井戸、自噴している三島市一 番町湓泉と柿田川湧泉群㧍よび三島溶岩流地下川主 流からは離れている三島市内の自噴井戸である谷田 小山、竹倉、大場の 6 地点において、溶存ガスなら びに環境同位体 $\left(\delta \mathrm{D} 、 \delta{ }^{18} \mathrm{O}\right)$ 分析用の地下水試料 $(15 \mathrm{~m} \ell)$ を 4 個づつおよび ${ }^{3} \mathrm{H}$ 分析ならびに溶存イ オン分析用地下水試料として各 $1000 \mathrm{~m} \ell$ を採水し た。 ${ }^{3} \mathrm{He}$ 分析用地下水採取は、1988年11月 9 ～10日 に行った。図ー 2 に地下水採取地点を示す。

3. 3 地下水水質、環境同位体比および ${ }^{3} \mathrm{He}$ 分析 (1)溶存イオン濃度分析; 測定項目は、 $\mathrm{Na}^{+} 、 \mathrm{~K}^{+}$、 $\mathrm{Ca}^{2+} 、 \mathrm{Mg}^{2+} 、 \mathrm{HCO}_{3}{ }^{-}$(以上JIS 規格による分析) 打 よびC $\ell-、 \mathrm{SO}_{4}{ }^{2-}$ (以上イオンクロマイトグラ フィーによる分析)である。分析結果を表ー 1 に示 す。この結果を基にへキサダイヤグラム(図ー2)な らびにキーダイヤグラム(図一 3 )を描いてみると、 三島溶岩地下川上に位置すると考えられる伊豆島 田、一番町抢よび柿田川湧水は殆んどへキサダイヤ
グラムの形状と大きさは一致し、キーダイヤグラム 上ではほとんど同じ位置にプロットされる。一方、 谷田小山、竹倉、大場の地下水のそれは、前述の 3 地点のものとは若干異なる。谷田小山のへキサダイ ヤグラムは前 3 者とほぼ相似形であるが、大きさは 大きい。このことは周辺岩盤との接触時間が長い可 能性を示唆している。また、竹倉ならびに大場のへ キサダイヤグラムの形状は、三島溶岩流地下水のも のとは異なることから地下水系が異なるものと想定 される。

(2)環境同位体比 $\left(\delta \mathrm{D} 、 \delta^{18} \mathrm{O}\right)$ 分析 ; 6 地点の分 析結果と富士山、箱根での降雪・降水、箱根地下水 ならびに芦ノ湖の表層水の分析結果(中井・水谷、

1985：Matsuo et al., 1979)とを図－4に天水線と共 に示す。 6 地点の地下水は、ほぼ天水線上に並ぶこ とによりこれら地下水の起源が降水起源であると判 断される。図ー4の中で伊豆島田、一番町、杮田川 の A 群と谷田小山、竹倉、大場のB群さらには、 箱根の地下水 $\mathrm{C}$ 群の地下水は、 $\delta \mathrm{D} 、 \delta{ }^{18} \mathrm{O}$ 比に若 干の差が認められる。A 群と B 群の違いは主に、地 下水の涵養された場所の違い、例えば高度効果に起 因する可能性が高い。また、B群の三島溶岩流内の 地下水は、C群である箱根地区の地下水とほぼ同程 度の気温条件下で涵養された地下水と考えられる が、 $\delta \mathrm{D}$ の比が若干異なることから箱根の地下水と は起源を異にするようである。このように見ると、 箱根以外の高所で涵養された地下水と考えられその 起源としては富士山あるいは、愛鷹山系で涵養され た地下水とも考えられる。

また、A 群の地下水は、B群ならびにC 群の地下 水より重い同位体に富んでおり、B 群(富士山系)あ るいはC 群(箱根山系)の地下水に平野部で降った 降雨が混って出来た地下水と解釈出来る。この $\mathrm{A}$ 群の地下水は、芦ノ湖の表層水(LA)ときわめて近 い同位体比を有して扔り、芦ノ湖の水が深良用水に よって深良川に流入し、三島の地下水の一部を涵養 している可能性が高いことを考えると、主に箱根山 系の地下水にによって涵養されていると解釈するの が妥当なようである。

(3) ${ }^{3} \mathrm{H}$ 濃度分析 ; (電解濃縮の後科技庁マニュアル による測定)は、全地点とも10T.U 以下 (表 -1 参 照)であり、最近の降水レベルとほぼ同程度である。 三島溶岩流内地下川上の 3 地点 $(6.9 \sim 9.1 \mathrm{~T}$.U)は、 他 3 地点(4.5〜7.0T.U)に比べ若干高いレベルにあ 


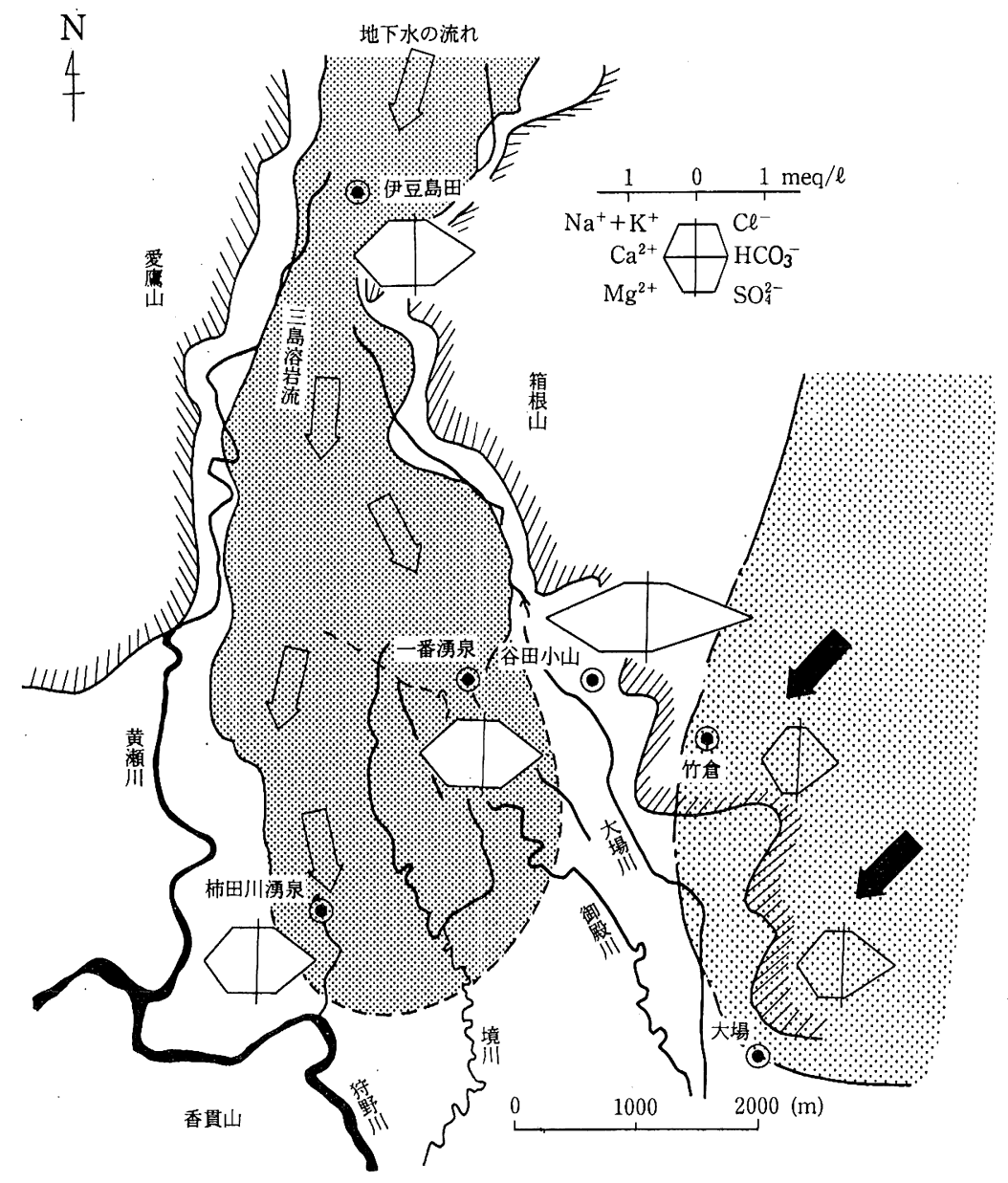

\section{図一２地下水採取位置とへキサダイヤグラムの大きさと地下水年代・環境同位体測定結果を基にした地 下水起源の分離}

Fig. 2. Sampling sites of groundwater in the Mishima groundwater basin and the hexa-diagram of dissolved cations and anions, the separation of groundwater sources based on the groundwater ages dating by the ${ }^{3} \mathrm{H}+{ }^{3} \mathrm{He}$ method and the measurement of the abundance of the stable isotopes, deuterium and oxygen-18.

る。

以上の(1)(2)(3)の結果から、三島溶岩流地下川上に 位置する伊豆島田、一番町、柿田川湧泉の地下水は 同一水系の地下水であり、谷田小山、竹倉および大 場の地下水とは水系が若干異なる。

3. $4{ }^{4} \mathrm{He}$ の起源とトリチウム起源 ${ }^{3} \mathrm{He}$ 濃度の評 価

伊豆島田、一番町、柿田川湧泉、谷田小山、竹倉、
大場の各地下水について ${ }^{4} \mathrm{He} 、\left({ }^{3} \mathrm{He} /{ }^{4} \mathrm{He}\right)$ 比抢よび $\left({ }^{20} \mathrm{Ne} /{ }^{4} \mathrm{He}\right)$ 比*1) の測定を行った。 ${ }^{4} \mathrm{He}$ 濃度は4.6 $\times 10^{-8} \sim 5.7 \times 10^{-8} \mathrm{ccSTP} / \mathrm{g}$ にあり、いづれの地 下水試料ともに三島地域の平均気温を $15^{\circ} \mathrm{C}$ とた際 の飽和 ${ }^{4} \mathrm{He}$ 溶解量 $4.55 \times 10^{-8} \mathrm{ccSTP} / \mathrm{g}$ よりも多い Heが溶けている。従って、1 気圧の大気中に含ま れる $\mathrm{He}$ と溶解平衡に達した量以上の過剩 $\mathrm{He}$ の溶解 が認められる。Sugisaki（1961)が明らかにした地 下水中の保存性の溶存希ガス量は、降水が地下に浸 
表一 1 地下水溶存イオン濃度と ${ }^{3} \mathrm{H}$ 濃度分析結果

Table 1. Concentration of the dissolved ions and concentration of tritium $\left({ }^{3} \mathrm{H}\right)$ in groundwater samples.

\begin{tabular}{|c|c|c|c|c|c|c|c|c|c|}
\hline 採水場所 & 採水日 & $\begin{array}{c}\mathrm{Na}^{+} \\
(\mathrm{m} g / \ell)\end{array}$ & $\begin{array}{c}\mathrm{K}^{+} \\
\left(\mathrm{m}^{g} / \ell\right)\end{array}$ & $\begin{array}{c}\mathrm{Ca}^{2+} \\
(\mathrm{m} g / \ell)\end{array}$ & $\begin{array}{c}\mathrm{Mg}^{2 *} \\
(\mathrm{~m} g / \ell)\end{array}$ & $\begin{array}{c}\mathrm{Cl}^{-} \\
(\mathrm{m} g / \ell)\end{array}$ & $\begin{array}{c}\mathrm{SO}_{4}^{2-} \\
(\mathrm{m} g / \ell)\end{array}$ & $\begin{array}{l}\mathrm{HCO}_{3}^{-} \\
(\mathrm{m} g / \ell)\end{array}$ & $\begin{array}{c}{ }^{3} \mathrm{H} \\
(\mathrm{T} . \mathrm{U} .)\end{array}$ \\
\hline 伊豆島田上水場 & $\begin{array}{l}(1988) \\
11 / 9\end{array}$ & 8.8 & 1.28 & 18.0 & 6.00 & 5.7 & 15.2 & 54 & $6.9 \pm 0.5$ \\
\hline 一番町勈 水 & $\begin{array}{l}(1988) \\
11 / 9\end{array}$ & 9.0 & 1.60 & 18.7 & 6.19 & 7.8 & 13.8 & 52 & $9.1 \pm 0.5$ \\
\hline 柿田川勈水 & $\begin{array}{l}(1988) \\
11 / 10\end{array}$ & 8.8 & 1.26 & 16.6 & 5.65 & 7.1 & 13.3 & 52 & $7.4 \pm 0.5$ \\
\hline 谷田小山 & $\begin{array}{l}(1988) \\
11 / 9\end{array}$ & 8.2 & 1.54 & 29.6 & 8.29 & 10.4 & 5.8 & 95 & $7.0 \pm 0.5$ \\
\hline 倉 & $\begin{array}{l}(1988) \\
11 / 9\end{array}$ & 4.4 & 0.55 & 11.1 & 2.96 & 3.1 & 1.4 & 36 & $4.5 \pm 0.5$ \\
\hline 場 & $\begin{array}{l}(1988) \\
11 / 10\end{array}$ & 5.8 & 1.42 & 13.6 & 4.09 & 3.9 & 1.8 & 46 & $6.0 \pm 0.5$ \\
\hline 検 出 限 界 & & 0.1 & 0.02 & 0.2 & 0.02 & 0.1 & 0.5 & 1 & 0.9 \\
\hline
\end{tabular}

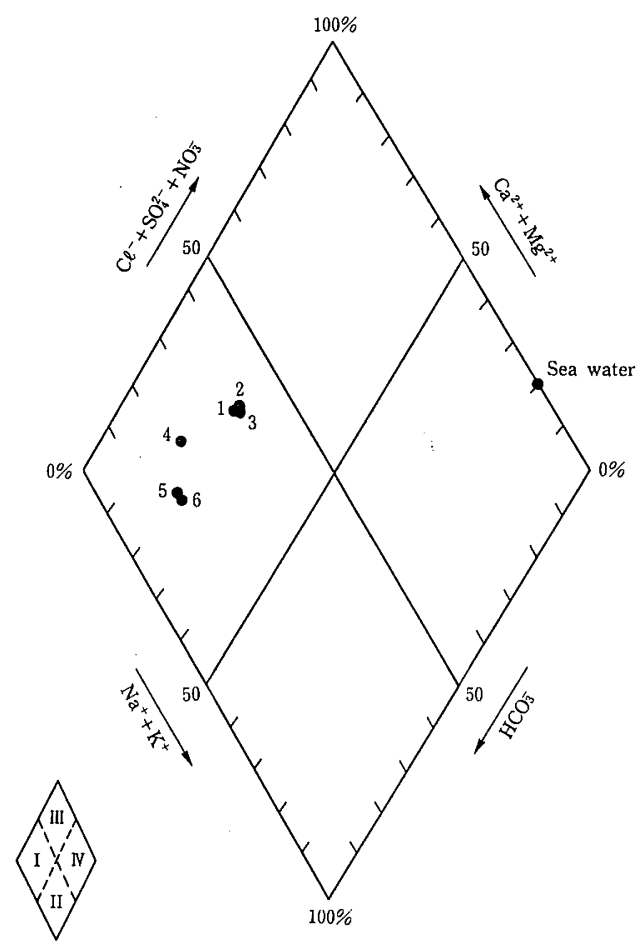

$\left.\begin{array}{l}\mathrm{I}: \mathrm{Ca}\left(\mathrm{HCO}_{3}\right)_{2} \text { 型の水(浅胎地 } 1 \text { 水) } \\ \mathrm{II}: \mathrm{NaHCO}_{3} \text { 型の水(深層地下水) }\end{array}\right\}$ 淡水

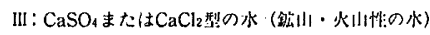

$\mathrm{N}: \mathrm{Na}_{2} \mathrm{SO}_{4}$ まなはNaCl梨の水(游水)
図ー3 三島地下水のキーダイヤグラム

Fig. 3. Distribution of groundwater samples in the Mishima groundwater basin in the key-diagram. 


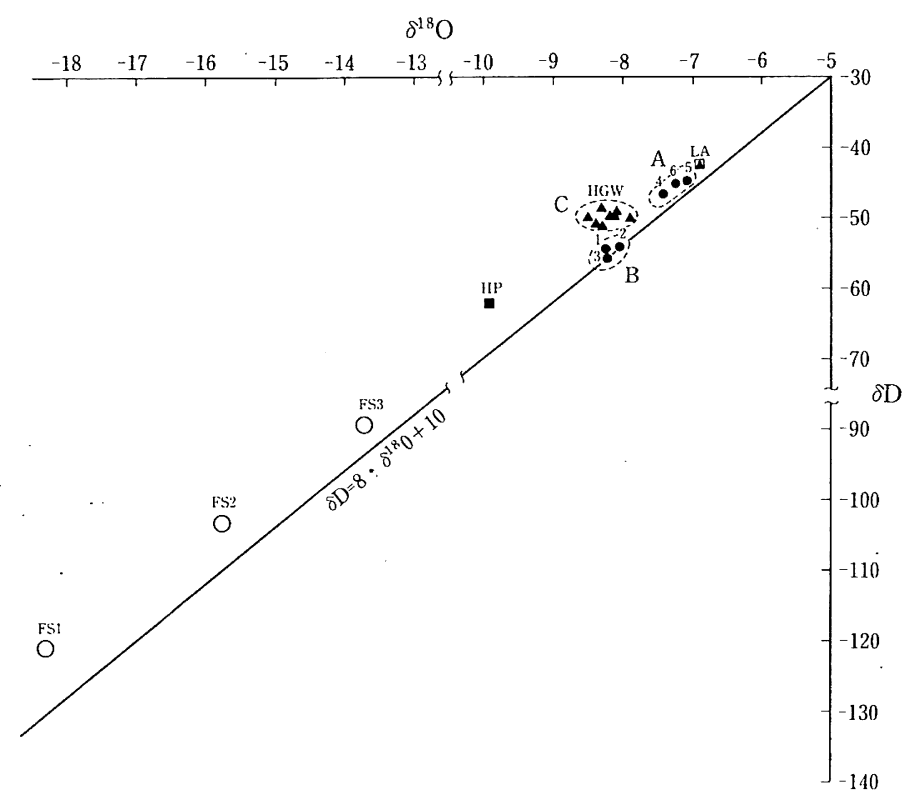

図一 4 三島地下水、箱根の地下水と降水、富士山の降雪ならびに芦ノ湖表層水の環境同位体比（ $\delta \mathrm{D} 、$ $\delta^{18} \mathrm{O}$ )の分布(箱根地下水、降水、芦ノ湖表層水は、Matsuo(1979)より引用; 富士山の降雪は、 中井・水谷(1985)より引用)

(1：伊豆島田、2：一番町湧泉、 $3:$ 柿田川湧泉、 $4:$ 谷田小山、 $5:$ 竹倉、6 $:$ 大場、 $\mathrm{HGW}$ : 箱根地下水、HP:箱根降水, LA : 芦ノ湖表層水、 $\mathrm{FS}_{1} 、 \mathrm{FS}_{2} 、 \mathrm{FS}_{3}$ : 富士山降雪)

Fig. 4. $\delta{ }^{18} \mathrm{O}$ values are plotted versus $\delta \mathrm{D}$ accompaning with the global meteoric water line. $\delta$ ${ }^{18} \mathrm{O}$ and $\delta \mathrm{D}$ of groundwater samples in the Mishima basin were measured in this study. Data of the groundwater, the rainwater and the surfacewater of the Lake Ashinoko in the Hakone area were cited from Matsuo's work (1979), and data of snow at the Mt. Fuji were cited from the study of Nakai and Mizutani (1985).

(1: Izushimada, 2: Ichibancho, 3: Kagitagawa, 4: Tanitakoyama, 5: Takekura, 6: Daiba, HGW : Groundwater of Hakone, HP : Averaged Precipitation at Hakone, LA : Surface Water of the Ashinoko Lake, $\mathrm{FS}_{1}, \mathrm{FS}_{2}, \mathrm{FS}_{3}$ : Snow of Mt. Fuji)

透し、地中で大気との接触を遮断された時の温度で の飽和溶解量を維持しているという研究成果と ${ }^{20} \mathrm{Ne}$ は地中での生成が無視でき、地下水中に溶解 している ${ }^{20} \mathrm{Ne}$ はすべて大気起源と考えられる事実 を基に、地下水の涵養温度を推定する。その結果、 1 気圧の大気中に含まれる ${ }^{20} \mathrm{Ne}$ の各温度での蒸留 水に対する飽和溶解量と比較することによって地下 水の涵養時の温度を推定できたものと、測定された ${ }^{20} \mathrm{Ne}$ 量が、2.25 $\times 10^{-7} \mathrm{ccSTP} / \mathrm{g}\left(0^{\circ} \mathrm{C}\right)$ の最大飽和溶 解量より多く、過剩空気が地下水の涵養時あるいは 採水時に取り込まれたと思われる試料とが存在する ことが明らかとなった。

${ }^{3} \mathrm{H}^{-}{ }^{3} \mathrm{He}$ 法で地下水年代を推定するには、 $\left({ }^{3} \mathrm{He} /\right.$ $\left.{ }^{4} \mathrm{He}\right)$ 比が著しく高いマントル・ヘリウム成分の混入 のないことを確認しておく必要がある。この点につ いては、以下のように評価した。まず、本研究で測 定されたデー夕、1気圧の大気中に含まれるへリウ ムと溶解平衡蒸留水デー夕、我国の花崗岩地帯で測 定した放射壊变生成へリウム成分の卓越した浅層地 下水デー夕、溶存ヘリウムの大部分を放射壊変生成 ヘリウム成分で占めている非常に古い地下水年代を 有しているオーストラリア大陸地下の深層地下水 データ(Torgersen. Clarke 1987)、明らかにマント ルヘリウム成分の混入が認められる熊本平野の地下 水(馬原、1992)と山形県の温泉水デー夕、トリチウ ムの壊変によって $\left({ }^{3} \mathrm{He} /{ }^{4} \mathrm{He}\right)$ 比の上昇が認められる 


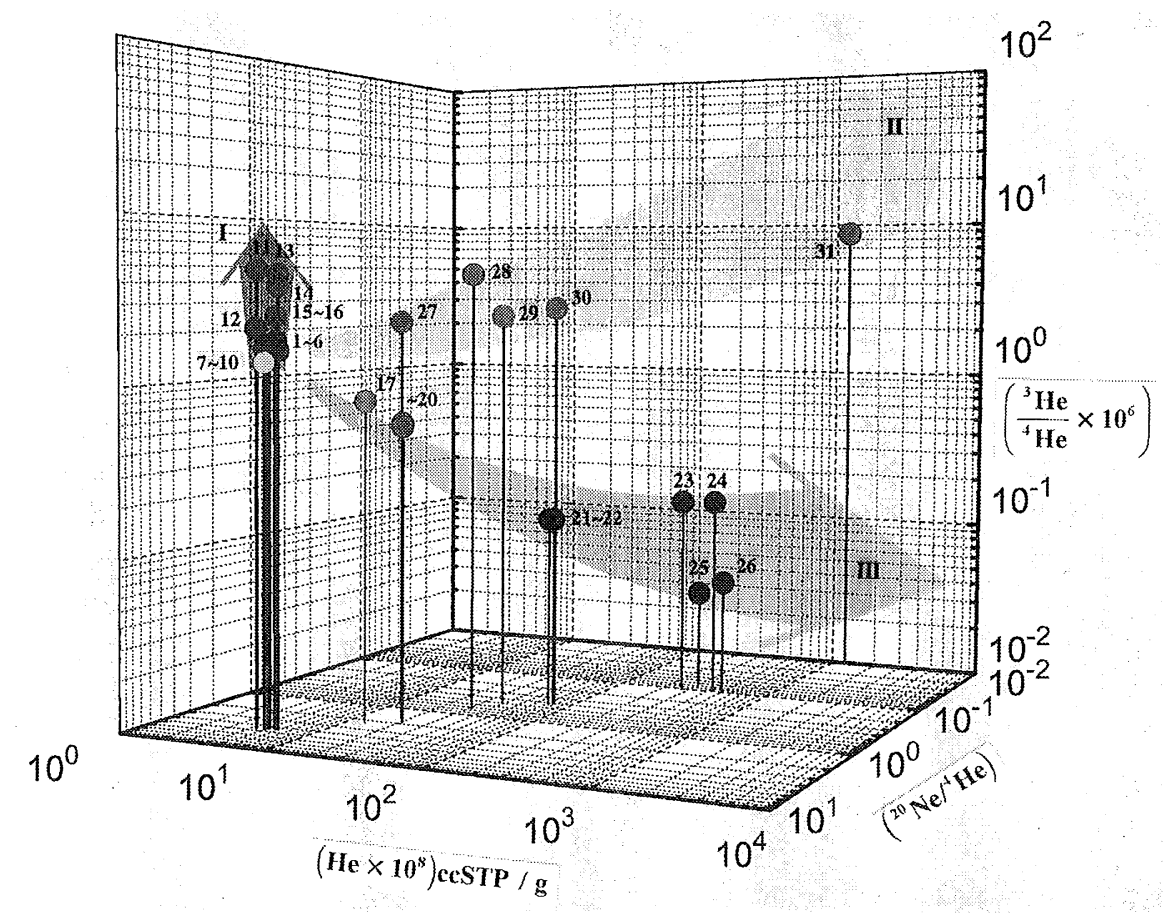

図一 5 種々の地下水サンプルに含まれる溶存へリウム量 $\left({ }^{3} \mathrm{He} /{ }^{4} \mathrm{He}\right)$ 比、 $\left({ }^{20} \mathrm{Ne} /{ }^{4} \mathrm{He}\right)$ 比の関係

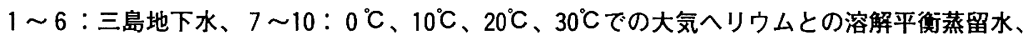
11 16: トリチウム起源 ${ }^{3} \mathrm{He}$ の增加の認められる堆積岩中浅層地下水、17 20: 放射壊変へリ ウム成分の蓄積により $\left({ }^{3} \mathrm{He} /{ }^{4} \mathrm{He}\right)$ 比の低下が認められる花崗岩中地下水、21 26: ${ }^{4} \mathrm{He}$ の蓄積 により $\left({ }^{3} \mathrm{He} /{ }^{4} \mathrm{He}\right)$ 比低下の著しい地下水年代 $10^{6}$ 年以上と見積もられているオーストラリア深層 地下水、27 30: マントルヘリウム成分の混入の可能性が高い熊本平野地下水、31: 山形県の温 泉水、I：トリチウム起源 ${ }^{3} \mathrm{He}$ の増加に伴い大気へリウム溶解平衡水の進化の方向、II : マン トルヘリウム成分の増加に伴い大気ヘリウム溶解平衡水の進化の方向、III : 放射壊変ヘリウム成 分の增加に伴い大気へリウム溶解平衡水の進化の方向、なお、11、12、31のデータは Takaoka • Mizutani(1987)、21〜26のデータは Torgersen・Clarke(1987)より引用した)

Fig. 5. Correlations among total content of dissolved helium, the ratio of ${ }^{3} \mathrm{He}$ to ${ }^{4} \mathrm{He}$, and the ratio of ${ }^{20} \mathrm{Ne}$ to ${ }^{4} \mathrm{He}$ in various groundwater samples.

(1 6: groundwater samples in the Mishima basin, 7 10: distilled water samples equilibrated with atmospheric helium at $0^{\circ} \mathrm{C}, 10^{\circ} \mathrm{C}, 20^{\circ} \mathrm{C}$, and $30^{\circ} \mathrm{C}, 11 \sim 16$ : shallow groundwater samples in Tertiary sediment with considerable increase of tritiogenic ${ }^{3} \mathrm{He}, 17 \sim 20$ : groundwater samples in granite area with decrease of the ratio of ${ }^{3} \mathrm{He}$ to ${ }^{4} \mathrm{He}$ caused by accumulation of radiogenic ${ }^{4} \mathrm{He}, 21 \sim 26$ : deep groundwater samples under the Australian continent, which are more than $10^{6}$ years old, with remarkable decrease of the ratio of ${ }^{3} \mathrm{He}$ to ${ }^{4} \mathrm{He}$ caused by accumulation of radiogenic ${ }^{4} \mathrm{He}, 27 \sim 30$ : groundwater samples collected in the Kumamoto Plain, which is suspected to be an intrusion of mantle helium component with high ratio of ${ }^{3} \mathrm{He}$ to ${ }^{4} \mathrm{He}, 31$ : hot-spring sample, I : evolutional trend of distilled water equilibrated with atmospheric helium with increase in tritiogenic ${ }^{3} \mathrm{He}, \mathrm{II}$ : evolutional trend of distilled water equilibrated with atmospheric helium with increase in the mantle helium component, $\mathbb{I I}$ : evolutional trend of distilled water equilibrated with atmospheric helium with increase in radiogenic helium component, Data for samples 11,12 and 31 are cited from Takaoka and Mizutani (1987) and data for samples $21 \sim 26$ are cited from Torgensen and Clarke(1987)). 
高岡平野の地下水 (Takaoka - Mizutani, 1987) と浅 層堆積岩中地下水データの三次元分布を図 -5 に示 す。この図から本研究で測定された 6 個のデー夕は、 ほぼ大気溶解平衡へリウムデータとトリチウム壊変 による $\left({ }^{3} \mathrm{He} /{ }^{4} \mathrm{He}\right)$ 比の上昇 $\left({ }^{20} \mathrm{Ne} /{ }^{4} \mathrm{He}\right.$ 比は大気溶解 平衡と同程度)デー夕域近傍に分布している。この ことは、本データでは、マントルヘリウムの混入の 可能性は、きわめて小さいと考えられる。

さらに、次のような Mamyrin・Tolstikhin(1984) やSano・Wakita(1985)、馬原(1992)等が、ヘリウ ム成分の分離に用いたのと同様なへリウム 3 成分 (トリチウム壊変と大気溶解混合ヘリウム成分、放 射壊変ヘリウム成分、マントルヘリウム成分)の $\left({ }^{3} \mathrm{He} /{ }^{4} \mathrm{He}\right)$ 比、 $\left({ }^{20} \mathrm{Ne} /{ }^{4} \mathrm{He}\right)$ 比の違いを活用したへ リウム三成分混合モデルを考え、各成分の混合割合 の評価を試みる。

\section{[三成分混合モデル]}

$[\mathrm{RHe}]_{\mathrm{S}}=[\mathrm{RHe}]_{\mathrm{at}} \cdot \mathrm{AT}+[\mathrm{RHe}] \mathrm{m} \cdot \mathrm{M}+$ $[\mathrm{RHe}] \mathrm{r} \cdot \mathrm{R}$

$[\mathrm{RNe}]_{\mathrm{s}}=[\mathrm{RNe}]_{\text {at }} \cdot \mathrm{AT}+[\mathrm{RNe}] \mathrm{m} \cdot \mathrm{M}+$ $[\mathrm{RNe}] \mathrm{r} \cdot \mathrm{R}$

$\mathrm{AT}+\mathrm{M}+\mathrm{R}=1$
ここに、[RHe]は $\left({ }^{3} \mathrm{He} /{ }^{4} \mathrm{He}\right)$ 比を、[RNe]は $\left({ }^{20} \mathrm{Ne}\right.$ $\left./{ }^{4} \mathrm{He}\right)$ 比を表す。s、at、m、r は各々、測定試料、 大気とトリチウム成分、マントル成分、放射壊変成 分を表す。また、AT、M、R は測定試料中に占め る各ヘリウム成分の存在割合を表す。また、Sano・ Wakita (1985) の研究から $[\mathrm{RHe}] \mathrm{m}=1.1 \times 10^{-5}$ 、 $[\mathrm{RHe}] \mathrm{r}=1.5 \times 10^{-8} 、[\mathrm{RNe}] \mathrm{m}=[\mathrm{RNe}] \mathrm{r}=0.001$ ま た、 $[\mathrm{RNe}]$ atとしては、推定涵養温度での 1 気圧の 大気に含まれるへリウムとネオンの溶解平衡時の值 を用いる。さらに、ここでは[RHe]at は大気へリウ ム成分と溶解平衡に達した後に降水中に含まれてい たトリチウムがすべて壊変して生成した ${ }^{3} \mathrm{He}$ が含ま れると仮定した $\left({ }^{3} \mathrm{He} /{ }^{4} \mathrm{He}\right)$ を用いることにすると、 $[\mathrm{RHe}] \mathrm{at}=1.93 \times 10^{-6}$ となる。この值は、降水中に 宇宙線起源によって生成されるトリチウムのみを含 む場合(Ravoire(1970)等)の值10T.U.程度を考えて いる。さらに、宇宙線起源のトリチウム生成レベル がKaufman(1954)等の提案レベル(5.5T.U.)にある とすると $[\mathrm{RHe}] \mathrm{at}=1.65 \times 10^{-6}$ となる。地下水中の 初期トリチウム・レベルが、10T.U.と5.5T.U.の 場合についてへリウム 3 成分の混合割合を計算した 結果を表一 2 に示す。また、初期トリチウムレベル

\section{表一 2 ヘリウム 3 成分 (大気十トリチウムヘリウム、マントルヘリウム、放射壊変ヘリウム)混合モデル によって評価した試料水中ヘリウムの混合割合}

Table 2. Mixing rates of helium components, which were estimated by the helium mixing model for three different helium components (atmospheric plus tritiogenic helium, mantle helium, and radiogenic helium), in groundwater samples in the Mishima basin.

\begin{tabular}{|c|c|c|c|c|c|c|}
\hline \multirow{2}{*}{ 採水場所 } & \multicolumn{3}{|c|}{ 5. $5^{* 1}$ T. U. の場合 (\%) } & \multicolumn{3}{|c|}{$10 * 2$ T. U. の場合 (\%) } \\
\hline & 大気十归私成分 & マントル成分 & 放射壊変成分 & 大気忛归的成分 & マントル成分 & 放射壊変成分 \\
\hline 伊豆島田 & 98.9 & 0.2 & 0.9 & 98.9 & $-2.3^{* 3}$ & 3. 4 \\
\hline 一番町涌 泉 & 94.8 & 0.8 & 4. 4 & 94.8 & -3.2 & 8. 4 \\
\hline 柿田川涌泉 & 89.5 & 1. 8 & 8. 7 & 89.5 & -0.4 & 10. 9 \\
\hline 谷田小山 & 92.9 & 2. 7 & 4. 4 & 92.9 & -0.9 & 8. 0 \\
\hline 倉 & 95.6 & 0.4 & 4. 0 & 95.6 & -2.0 & 6. 4 \\
\hline 大 & 97.5 & 1. 3 & 1. 2 & 97.5 & -1.2 & 3. 7 \\
\hline
\end{tabular}

*1: 降水によって洒娘された地下水中のトリチウムのすへてが、宇宙線起源によってのみ与えられると仮定した際の

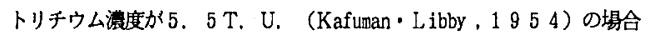

*2: 降水によって洒巷された地下水中のトリチウムのすへてが、宇宙線起源によってのみ与えられると仮定した際の トリチウム漕度か1 0 T. U. （Ravoire et al., 1970 ）の場合

*3 : マントMリウム成分がマイナス (-) ということは、初期トリチウム濃度が 10 T. U. の場合には、 マントルリウム成分の混入は考えられないことを意味している。 
と $\left({ }^{3} \mathrm{He} /{ }^{4} \mathrm{He}\right)$ 比、 $\left({ }^{20} \mathrm{Ne} /{ }^{4} \mathrm{He}\right)$ 比の関係を図ー6の A に示す。また、降水中のトリチウムレベルは、 1963年に大気圈内での熱核実験の影響により、最大 約1100T.U.に達した後、急激に減少したが、関東 近辺では、1970年代 1980年代前半までは、そのレ ベルは平均で20T.U.を上回っていた(榧根、他1980、 木村、1986)。したがって、1970年代から1980年代 前半の三島周辺の降水のトリチウムレベルが20T. U.程度あったと考えても大きな間違いはないもの と考えられる。その場合には、表一2の初期トリチ ウム濃度10T.U.の結果からマントルヘリウム成分 の混入の可能性はほとんどないものと考えられる。

$\left({ }^{3} \mathrm{He} /{ }^{4} \mathrm{He}\right)$ 比と $\left({ }^{4} \mathrm{He} /{ }^{20} \mathrm{Ne}\right)$ 比の関係ならびに、 $\left({ }^{3} \mathrm{He} /{ }^{4} \mathrm{He}\right)$ 比と ${ }^{3} \mathrm{H}$ 濃度との関係等を図一 6 に示す。 図一 5 ならびに図ー 6 の A では、初期にある ${ }^{3} \mathrm{H}$ 濃 度を持った降水によって涵養された地下水が、地中 で滞留時間の増加と供に、周辺岩盤から供給される $\mathrm{He}$ の增加によって $\left({ }^{20} \mathrm{Ne} /{ }^{4} \mathrm{He}\right)$ が初期の ${ }^{3} \mathrm{H}$ 濃度線 上を減少する様子と実測されたデー夕との関係を示 しているが、この結果から判断するとこの地域の地 下水がすべて降雨を起源としていることと、大きな $\mathrm{He}$ の蓄積は認められないことから、非常に古い地 下水の混入はあまりない比較的若い地下水と解釈さ れる。また、図一6のDからは、各試料水中に溶
存している ${ }^{3} \mathrm{H}$ 起源の ${ }^{3} \mathrm{He}$ 量と地下水涵養時の初期 ${ }^{3} \mathrm{H}$ 濃度と経過時間(地下水年代)との関係が示され て抢り、採水時点で10年前後経過していることを示 している。但し、一番町の湧水のみは、その滞留時 間が短く、ごく近年の降水を起源としていることが 図一6のB、C、Dの結果からも理解できる。

\section{5 地下水年代の評価}

地下水年代の推定方法は、Torgersen et al(1979) と Schlosser et al(1988、1989)が用いた方法によっ て行った。Torgersen と Schlosserの方法では、地 下水の涵養時温度を推定する必要があり、ここでは 前述の ${ }^{20} \mathrm{Ne}$ の溶存量より涵養温度を推定する方法 を用いた。また、最大飽和溶解量より多い ${ }^{20} \mathrm{Ne}$ を 含む試料については、この方法では推定できないの で三島の平均気温 $15^{\circ} \mathrm{C} て ゙$ 涵養したものとして評価し た。 ${ }^{3} \mathrm{He}$ 評価結果を基に推定した地下水年代は、表 -3 に示すように伊豆島田で 9.9 年、一番町湧泉で $3.7 \sim 5.7$ 年、柿田川湧泉で10 10.9年であった。こ れらの内で、一番町湧泉は、例年は11月頃より冬期 (渴水期)には枯渴していることが多いが1988年は、 7 月〜 9 月の長雨の影響で11月に拈いても湧水があ り、そのためにごく最近の降水がかなりの量含まれ ているために滞留時間を非常に短くしているものと

表一 3 地下水中溶存 $\mathrm{He}$ 量、 $\left({ }^{3} \mathrm{He} /{ }^{4} \mathrm{He}\right)$ 比 $\left({ }^{20} \mathrm{He} /{ }^{4} \mathrm{He}\right)$ 比と地下水年代

Table 3. Concentration of the dissolved helium-4, ratio of $\left.{ }^{3} \mathrm{He} /{ }^{4} \mathrm{He}\right)$ and ratio of $\left({ }^{20} \mathrm{He} /{ }^{4} \mathrm{He}\right)$ in groundwater samples and the calculated ages of groundwater.

\begin{tabular}{|c|c|c|c|c|c|}
\hline \multirow{2}{*}{ 埰水堨所 } & \multirow{2}{*}{$\begin{array}{l}\text { 溶存“"He量 } \\
\text { (ccSTP/g) }\end{array}$} & \multirow{2}{*}{${ }^{\mathrm{He} /} / \mathrm{He}{ }^{* 1}$} & \multicolumn{2}{|c|}{ 計算された地下水年代（年） } & \multirow{2}{*}{${ }^{20} \mathrm{Ne} /{ }^{4} \mathrm{He}$} \\
\hline & & & Torgersen の法 & Schlosserの法 & \\
\hline 伊豆島田上水場 & $4.70 \times 10^{-3}$ & $1.65 \times 10^{-8}$ & 9.9 & 9.9 & $4.34 \cdots$ \\
\hline 一 番 町 涌 泉 & $5.15 \times 10^{-8}$ & $1.48 \times 10^{-8}$ & 5.7 & 3.7 & $\begin{array}{l}4.35^{* 3} \\
\left(0^{\circ}\right)^{-3}\end{array}$ \\
\hline 柿 田川 诵 泉 & $4.60 \times 10^{-8}$ & $1.68 \times 10^{-6}$ & 10.9 & 10.0 & $\begin{array}{l}3.93^{* 9} \\
\left(8^{\circ}\right)\end{array}$ \\
\hline 谷田小山 & $5.66 \times 10^{-8}$ & $1.83 \times 10^{-6}$ & 15.1 & 16.0 & $\begin{array}{l}4.35 * 2 \\
\left(15^{\circ}\right)\end{array}$ \\
\hline 倉 & 5. $63 \times 10^{-8}$ & $1.62 \times 10^{-6}$ & 12.9 & 14.0 & $\begin{array}{l}4.17^{* 2} \\
\left(15^{\circ}\right)\end{array}$ \\
\hline 大 & $4.91 \times 10^{-8}$ & 1. $75 \times 10^{-6}$ & 13.4 & 14.1 & $\begin{array}{l}4.33 * 2 \\
\left(15^{\circ}\right)^{* 2}\end{array}$ \\
\hline
\end{tabular}

*1：標染空気 $\left({ }^{3} \mathrm{He} /{ }^{4} \mathrm{He}\right)=1,400 \times 10^{-6}$

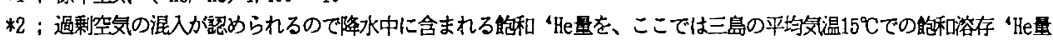
$\left(4.55 \times 10^{-8} \mathrm{ccSTP} / \mathrm{g}\right)$ と仮定した。

*3; 溶存 ${ }^{2} \mathrm{Ne}$ より推定した地下水晸警温度 


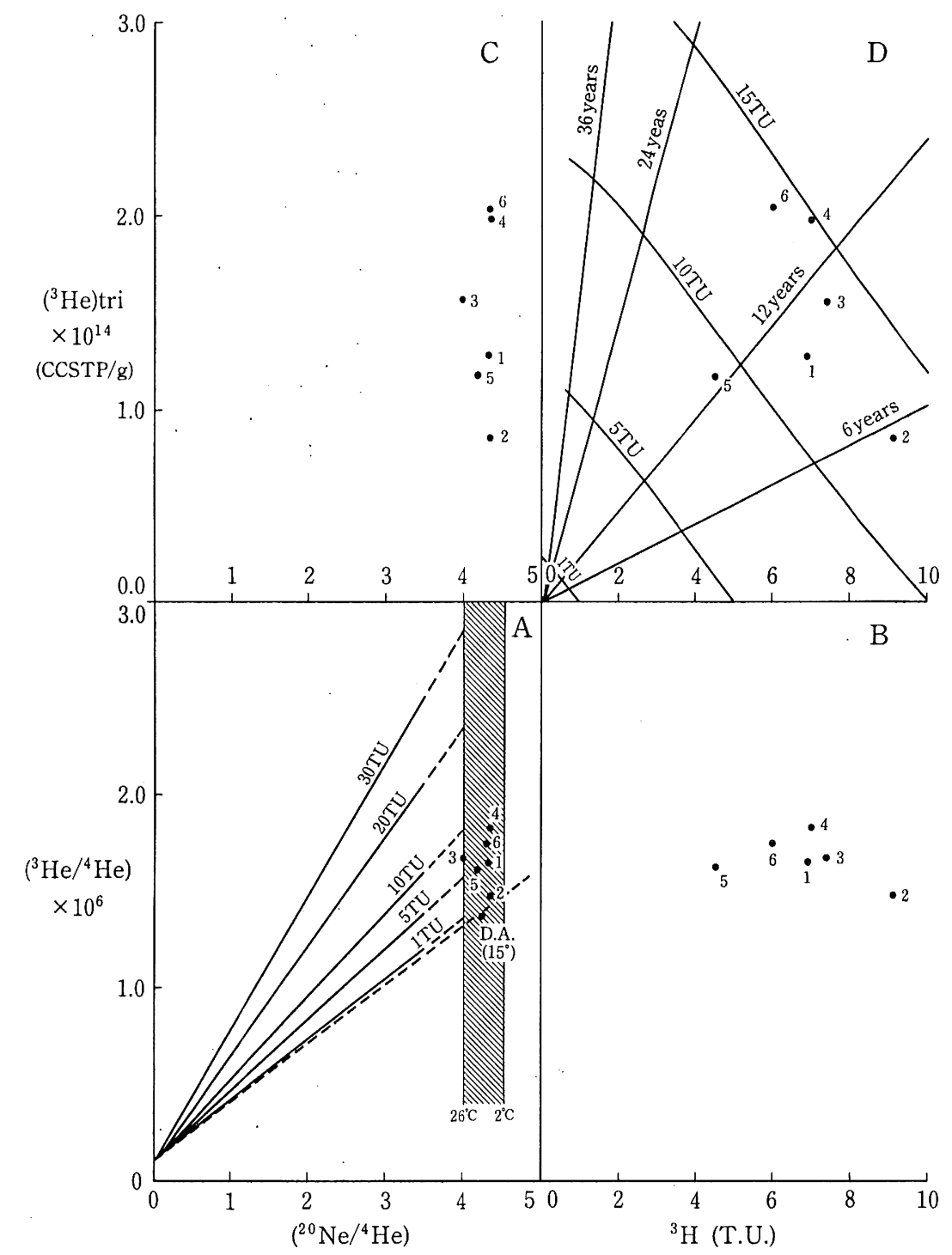

図一 6 三島地下水サンプルの $\left({ }^{20} \mathrm{Ne} /{ }^{4} \mathrm{He}\right)$ 比と $\left({ }^{3} \mathrm{He} /{ }^{4} \mathrm{He}\right)$ 比、 ${ }^{3} \mathrm{H}$ と $\left({ }^{3} \mathrm{He} /{ }^{4} \mathrm{He}\right)$ 比、 $\left({ }^{20} \mathrm{Ne} /{ }^{4} \mathrm{He}\right)$ 比と トリチウム起源 ${ }^{3} \mathrm{He}$ 量と ${ }^{3} \mathrm{H}$ とトリチウム起源 ${ }^{3} \mathrm{He}$ 量の関係

( 1 : 伊豆島田、2:一番町湧泉、 $3:$ 柿田川湧泉、 $4:$ 谷田小山、 $5:$ 竹倉、 $6:$ 大場)

Fig. 6. Correlations among ${ }^{4} \mathrm{He},{ }^{20} \mathrm{Ne},{ }^{3} \mathrm{H}$ and tritiogenic ${ }^{3} \mathrm{He}$ in groundwater samples of the Mishima basin are plotted: $\mathrm{A}$ indicates the correlation between the ratio of $\left({ }^{3} \mathrm{He} /{ }^{4} \mathrm{He}\right)$ and the ratio $\left({ }^{20} \mathrm{Ne} /{ }^{4} \mathrm{He}\right)$ drawing together the relation between the initial ${ }^{3} \mathrm{H}$ concentration of groundwater and the decrease of the ratio of $\left({ }^{20} \mathrm{Ne} /{ }^{4} \mathrm{He}\right)$ with the elapsing time, $\mathrm{B}$ indicates the correlation between the ratio of $\left({ }^{3} \mathrm{He} /{ }^{4} \mathrm{He}\right)$ and ${ }^{3} \mathrm{H}, \mathrm{C}$ indicates the correlation between the ratio of $\left({ }^{20} \mathrm{Ne} /{ }^{4} \mathrm{He}\right)$ and the tritiogenic ${ }^{3} \mathrm{He}, D$ indicates the correlation between ${ }^{3} \mathrm{H}$ and the tritiogenic ${ }^{3} \mathrm{He}$ drawing together the relation between the initial ${ }^{3} \mathrm{H}$ concentration of groundwater and the increase of the tritiogenic ${ }^{3} \mathrm{He}$ with the elapsing time. (1: Izushimada, 2: Ichibancho, 3: Kagitagawa, 4: Tanitakoyama, 5: Takekura, 6: Daiba) 
予想される。一番町湧泉を除く伊豆島田と柿田川涌 泉を結ぶ三島溶岩流地下川の地下水の滞留時間とし ては、10年前後と推定される。この結果は、落合 · 川崎等(1970)が、1965 1968年にかけて、 ${ }^{3} \mathrm{H}$ 濃度 のみを指標として、核実験の降水の最大 ${ }^{3} \mathrm{H}$ 濃度ピー クを用いた年代測定によって推定した10年以下とい う結果ともあまり大差ない。今回測定した範囲では、 最も古い地下水年代は、谷田小山の15.1 16年で あった。また、竹倉、大場の地下水が三島溶岩流地 下水より若干古い年代を示すことは箱根山系の梁層 地下水の中には、数10年以上という滞留時間を有す 地下水が存在するという落合 ・ 川崎(1970)の結果と もよい相関を持っている。

伊豆島田と柿田川湧泉群までの距離を $6000 \mathrm{~m}$ とし て上記地下水年代を基に地下水の実流速を概算する と $16 \mathrm{~m} /$ day となる。また、伊豆島田と杮田川湧泉 との直線距離 $6000 \mathrm{~m}$ と 2 点の水頭差 $60 \mathrm{~m}$ 、つまり動 水勾配 0.01 とし平均透水係数を $0.029 \mathrm{~m} / \mathrm{sec}$ とし て、ダルシー流速を求めると $25 \mathrm{~m} / \mathrm{day}$ となる。溶 岩流の平均空隙率を 30 ～ $40 \%$ 程度と考えると実流速 は60 80m/day となる。

一方、金子・落合(1966)等が、ラジオアイソトー プ流速計を用いて三島溶岩流層が愛鷹山と箱根山に 挟まれて最も狭くなっている伊豆島田付近で測定し た流速は、0.01〜 800 m/ day と非常に大きな幅を 持っている。これらの結果と最近の三島溶流の構造 に関する研究成果(土、1990)を合わせて判断すると、 地下水流としては非常に速く流れている部分と、き わめてゆるやかに流れている部分とが共存するもの と考えられる。 ${ }^{3} \mathrm{H}-{ }^{3} \mathrm{He}$ 法による年代測定をべース とした地下水流速と、Darcy 則で求めた結果が、 3 〜 5倍の範囲で一致することから考えると過去の研 究(蔵田、1962：金子・落合、1966)に扔いて述べら れてきた、三島溶岩流内の地下水は、涵養源である 富士山から数ヶ月で流下し流出しているとの推定結 果は否定しなければならない。

一般水質・環境同位体ならびに地下水年代測定結 果から判断すると、三島溶岩流内の地下水は、周辺 地下水とはその涵養源を異にしており、特に箱根山 系の地下水とはその起源が異なると判断できる。 その結果、三島地区の地下水は、富士山系の地下 水によって涵養されている三島溶岩流地下水領域と 箱根山系の地下水によって涵養されている領域とに 分けられる。三島溶岩流内の地下水は、その年代は
ほぼ10年、東側の箱根山系の地下水は、それょり若 干古い15年前後の地下水が分布している(図-2 参 照)。

\section{4.まとめ}

水質・環境同位体ならびに ${ }^{3} \mathrm{H}-{ }^{3} \mathrm{He}$ 法による地下 水年代測定を行った結果ならびに過去の水理地質調 查結果を踏まえて判断すると、三島地区の地下水の 流動区分ならびに涵養源の特定が可能であるとの結 論を得た。これらの結果は、今後の地下水調査に㧈 いては、Darcy 則を基礎とする地下水位、透水係数 測定に加えて新に地球化学的観点からの環境同位体 測定ならびに ${ }^{3} \mathrm{H}^{3} \mathrm{He}$ 法による年代測定を加えるこ とにより、従来からの調查手法だけからでは得られ ない地下水の流動に関する有力な情報が得られるこ とを示唆している。

注 $1:\left({ }^{20} \mathrm{Ne} /{ }^{4} \mathrm{He}\right)$ は、今回の測定では、測定器の 都合により ${ }^{4} \mathrm{He}\left({ }^{3} \mathrm{He} /{ }^{4} \mathrm{He}\right)$ 比とは同時に測定 ができなかったので、後日、保存用別試料 (同 一場所、同一深度、同一日時に同じ方法で 採取した)を用いて $\left({ }^{20} \mathrm{Ne} /{ }^{4} \mathrm{He}\right)$ 比を測定した 結果である。

\section{参 考 文 献}

落合敏郎・川崎宏直(1970)：溶岩流地下水流動に関する研 究、農業土木試験場報告第 8 号、67-82.

殹根 勇・田中 正・嶋田 純(1980): 環境トリチウムで 追跡した関東口ーム層中の土壤水の移動、地理学評論、 53、225-237.

金子 良・落合敏郎(1966)：富士山ろく地域の水資源に関 する研究、三島およびその周辺地域の水収支、農業土木 試験場技報、A. 第 1 号、1-22.

北岡豪一(1983)：トリチウムによる浅層地下水の滞留時間 の推定、水温の研究、26、25-34.

北岡豪一・吉岡龍馬(1984)：トリチウム濃度から推定され る六甲山系の水循環の速さについて、日本地下水学会誌、 26、131-145.

木村重彦(1986)：水に含まれる放射性同位体による地中水 の挙動解析、農業土木試験場報告、25号、1-19.

藏田延男(1962) : 静岡県三島市拉よびその近郊の地下水 理、工業用地下水調査特報 II 、工業用水、43、39-47.

土 隆一(1990): 富士山簏の地下水、日本地下水学会、 1990年 秋季講演会講演要旨、16-19.

中井信之・水谷義彦(1985)：安定同位体による流域の比較 
研究一降水 · 河川水 - 地下水の同位体比一比較河川学 の研究、文部省科学研究費特定研究 (I) 研究成果 (比較 河川学60-2)52-63.

馬原 保典 (1992)：溶存希ガス分析による熊本平野地下水 の年代測定、土木学会第47回年次学術講演会講演概要集 第 2 部、pp. 582-583.

水谷義彦・小田松尚 (1983) : 安定同位体比による富山県庄 川扇状地地下水のかん養源および流動状況の研究、地球 化学、17、1-9.

本島 勲(1987)：岩盤地下水の水質・同位体調查一地下 水の年代に関する検討(3)、電力中央研究所 研究報告 : U86047.

吉岡龍馬 - 出井 紘 - 富野孝生 - 田中稔章 - 豊田恵聖 - 高 橋正美(1979)：溶存アルゴンからみた地下水の動き(1)、 京大防災研究所年報、22号 B1、1-12.

Andrews J.N., Dauis, S.N., Martin, J.F., Fontes, J.C., Lehmann, B.E., Loosli, H.H., Michelot, J.L., Moser, H., Smith, B. and Wolf, M., (1989): The in situ production of radioisotopes in rock materials with particular reference to the stripa granite. Geochimica Cosmochimica Acta, 53 , 1803-1815

Bentley H.W., Philips F.M., Stanley N.D., Harbermehl M.A., Airey P.L., Calf G.E: Elmore D. Gore H.E: Torgersen T. (1986): Chlorine 36 dating of very old groundwater 1. The great Artesian Basin, Australia, Water Resource Research 22, 1991-2001.

Burgman J.O.S: Eriksson E: Kostov L: Möller. Ȧ (1978): Application of oxygen-18 and deuterium for investigating the origin of groundwater in connection with a dam project in Zambia (IAEA-SM-228/3), Isotope hydrology, Vol.1, $27-42$.

Graham, D.W., Jenkins, W.J., Kurz, M.D., and Batiza, R., (1987): Helium isotope disequilibrium and geochronology of glassy submarine basalts, Nature, 326, 384-386.

Kamensky, I.L., Toharev, I.V. and Tolstikhin, I.N. (1991): ${ }^{3} \mathrm{H}-{ }^{3} \mathrm{He}$ dating A case for mixing of young and old groundwaters, Geochimica Cosmochimica Acta, 55, 2895-2899.

Kaufman S. and Libby, W.F. (1954): The natural distribution of tritium, Phys. Rev., 93, 1337-1344.

Kaufman J.W. (1961): Tritium as a groundwater tracer, ASCE Transaction pap.No.3203, 436-446.

Mamyrin B.A. and Tolstikhin I.N. (1984): Helium Isotopes in Nature, pp.273, Elsevier, Amsterdam, Netherlands.

Martin J.F., Bentley H., Elmore D. and Airey P.L. (1985): Natural iodine-129 as an enviromental tracer, Geochimica Cosmochimica Acta, 49, 337-347.

Matsuo, S., Kusakabe, M., Niwano, M., Hirano, T. and Oki, Y. (1979): Water budget in the Hakone caldera using hydrogen and oxygen isotope ratios, Isotopes in Lake studies (IAEA), 131-141.

Morrison, P. and Pine, J. (1955): Radiogenic origin of the helium isotopes in rock, New York Academy of Sciences,
62, 69-92.

Paul M: Kaufman A: Magaritz M: Fink D: Henning W: Kaim R: Kutschera W: Meirav O. (1986): A new ${ }^{36} \mathrm{Cl}$ hydrological model and ${ }^{36} \mathrm{Cl}$ systematics in the Jordan River/Dead Sea System, Nature, 321, 511-515.

Philips F.M : Bently H.W: Stanley N.D: Elmere D: Swanik G.B. (1986): Chlorine 36 dating of very old groundwater 2. The Milk River aquifer, Albarta, Canada, Water Resources Research, 22, 2003-2016.

Poreda, R.J., Cerling, T.E., and Salomon, D. K., (1988): Tritium and helium isotopes as hydrologic tracers in a shal. low unconfined quifer, J. Hydrology, 103, 1-9

Rauert W.: Stichler W (1974): Groundwater investigations with environmental isotopes (IAEA-SM-182/24), Isotope Techniques in Groundwater Hydrology, Vol.1. 431-441.

Rodhe A (1983): Groundwater contribution to stream flow in Swedish forestedtill soil as estimated by oxygen-18 (IAEA-SM-270/65), Isotope hydrology, 55-66.

Sano, Y., Nakamura, Y., and Wakita H., (1984): Helium-3 emission related to volcanic activity, Science, 224 . 150-151.

Sano, Y. and Wakita, H., (1985): Geographical distribation of ${ }^{3} \mathrm{He} /{ }^{4} \mathrm{He}$ ratios in Japan: Implications for Arc tectonies and incipient magmatism, J. Geophysical Research, 90, B-10, 8729-8741.

Schlosser, P., Stute, M., Dörr, H., Sonntag, C. and Münnich, K.O. (1988): Tritium $/{ }^{3} \mathrm{He}$ dating of shallow groundwater, Earth Plant. Sci. Lett., 89, 353-362.

Schlosser, P., Stute, M., Sonntag, C. and Münnich, K.O., (1989): Tritiogenic ${ }^{3} \mathrm{He}$ in shallow groundwater, Earth Plant. Sci. Lett., 94, 245-256.

Solomon, D.K. and Sudicky, A.E. (1991): Tritium and helium 3 isotope ratio for direct estimation of spatial variations in groundwater recharge, Water Resources Res., 27. 2309-2319.

Stute, M., Sonntag, C., Deák, J. and Schlosser, P. (1992) : Helium in deep circulating groundwater in the Great Hungarian Plain: Flow dynamics and crustal and mantle helium fluxes, Geochimica Cosmochimica Acta, 56, 2051-2067.

Sugisaki R. (1961): Measurement of effective flow velocity of groundwater by means of dissolved gases, Am. J. Science, 259, 144-153.

Takaoka, N. and Mizutani, Y. (1987): Tritiogenic ${ }^{3} \mathrm{He}$ in groundwater in Takaoka, Earth Planet. Sci. Lett., 85, 74-78.

Torgersen, T., Top. Z., Clarke W.B., Jenkins W.J. and Broocker, U.S. (1977): A new method for physical limnology-tritium/helium-3 ages-results for Lake Erie, Huron and Ontario, Limnol. Oceanogr., 22, 181-193.

Torgersen, T., Clarke, W.B., and Jenkins, W.J. (1979): The tritium/helium-3 method in hydrology, in: Isotope Hydrol- 
ogy 1978, Vol. II. 917-930, (IAEA-SM-228/49).

Torgersen, T., and Clarke, W, B. (1987): Helium accumulation in groundwater, III. Limits on helium transfer across the mantle-crust boundary beneath Australia and the magnitude of mantle degassing, Earth and Planetary Science
Letters, 84, 345-355.

Weiss, R.F. (1968): Piggyback sampler for dissolved gas studies on sealed water samples, Deep-Sea Res., 15, 695-699. 